\title{
Identification of Fusarium Species Associated with Onion (Allium cepa L.) Plants in Field in Burkina Faso
}

\author{
Konwendé Raïssa Kintega1,2*, P. Elisabeth Zida ${ }^{1}$, Vianney W. Tarpaga ${ }^{1}$, Philippe Sankara², \\ Paco Sereme ${ }^{1}$
}

${ }^{1}$ Laboratoire de Phytopathologie Institute de l'Environnement et de Recherches Agricoles (INERA), Ouagadougou, Burkina Faso

${ }^{2}$ Université Joseph Ki-ZERBO, Ouagadougou, Burkina Faso

Email: *kintegarassa@yahoo.fr

How to cite this paper: Kintega, K.R., Zida, P.E., Tarpaga, V.W., Sankara, P. and Sereme, P. (2020) Identification of Fusarium Species Associated with Onion (Allium cepa L.) Plants in Field in Burkina Faso. Advances in Bioscience and Biotechnology, 11, 94-110. https://doi.org/10.4236/abb.2020.113008

Received: February 5, 2020

Accepted: March 27, 2020

Published: March 30, 2020

Copyright $\odot 2020$ by author(s) and Scientific Research Publishing Inc. This work is licensed under the Creative Commons Attribution International License (CC BY 4.0).

http://creativecommons.org/licenses/by/4.0/

\section{(c) (i) Open Access}

\begin{abstract}
Many fungi limit onion production in Burkina Faso. This study aims to identify the main Fusarium species associated with onion plant in field in order to determine those involved in seedling damping-off and bulb rot, and develop adequate management strategies of these diseases. For this purpose, 36 isolates of Fusarium were isolated from onion plants in 17 sites and subjected to molecular analysis and biometric characterization. The results revealed that the isolates belong to five Fusarium species: Fusarium oxysporum $(44.44 \%$ of the isolates), Fusarium proliferatum (41.66\%), Fusarium solani (5.55\%), Fusarium fujikuroi (5.55\%) and Fusarium thapsinum (2.77\%). Fusarium oxysporum, $F$. proliferatum, $F$. solani and $F$. fujikuroi had faster mycelial development, with a growth rate of $7.72-8.27 \mathrm{~mm} / \mathrm{d}$, than $F$. thapsinum (6.52 $\mathrm{mm} / \mathrm{d}$ ). Conidia of $F$. oxysporum, $F$. proliferatum and $F$. solani were longer $(4.74-5.96 \mu \mathrm{m})$ than those of $F$. fujikuroi and $F$. thapsinum $(3.20-4.04 \mu \mathrm{m})$. Fusarium solani and F. oxysporum, respectively, had the largest and most partitioned conidia.
\end{abstract}

\section{Keywords}

Allium cepa, Fusarium, Molecular Identification, Biometric Characterization, Fungal Rot

\section{Introduction}

Onion is produced all over the world. Its production in West African countries 
represents less than $1 \%$ of the world production. Burkina Faso is ranked 4th West African onion producing country after Nigeria, Niger and Senegal [1], each with just over 3\% of the regional production. Among the off-season crops grown in Burkina Faso, the bulb onion ranks second after the tomato, accounting for $32.4 \%$ and $41.4 \%$ of the total vegetable crops production and areas, respectively [2]. In Burkina Faso, onion production presents disparities. Since the 2009/2010 season, four main production regions have accounted for about $70 \%$ of national production. These are, in order of importance, the Boucle of Mouhoun region, the North region, the Center-North region and finally the Center-West region [3]. In general, onion cultivation provides important income for a multitude of actors, contributing to job creation and a better living environment for producers. Onions are very appreciated for their flavour and nutritional value. It is rich in vitamins and trace elements and the main nutrients in bulbs and leaves are diverse and their contents sometimes high. One hundred grams (100 g) of onion contains $7 \mathrm{mg}$ of vitamin C; $0.14 \mathrm{mg}$ of vitamin B6; $170 \mathrm{mg}$ of Potassium, corresponding to $9 \%, 5 \%$ and $5 \%$ of the daily nutrient intake [4].

Despite the nutritional and economic importance of onion, its cultivation faces several biotic and/or abiotic constraints limiting its production. Fungal diseases are responsible for the estimated yield losses between $30 \%$ and $40 \%$ of the crop [5] and are the main biotic constraints to production. Diseases such as basal bulb rot are mainly caused by fungi of the genus Fusarium, also known to be responsible for seedling damping-off [6]. Fusarium oxysporum is the bestknown, pathogenic species responsible for wilting, root rot and crown rot on a variety of crops and often resulting in significant production losses [7]. Several authors have reported that $F$. oxysporium is the causal agent of basal onion rot [6] [8]. Zlata et al. [9] and Ghanbarzadeh et al. [10] have highlighted the responsibility of $F$. solani in the decay of the basal parts of onion plants leading to their sudden death. The importance of Fusarium species in onion cultivation in Burkina Faso has been poorly investigated. The only works are those of Dabiré [11] which have highlighted the involvement of F. oxysporium and F. solani in damping-off on seedlings and rotting of underground parts and bulbs in conservation. Accurate knowledge of the identity of a pathogen responsible for a given disease is the first step towards implementing adequate disease control and surveillance measures [12]. The identification of Fusarium species is made difficult because of the absence of discriminatory cultural or morphological characteristics. However, the molecular tool, particularly DNA sequencing, has emerged as a key means of identifying pathogenic fungi regardless of their stage of development and their morphology.

The objective of this study was to identify and characterize at the molecular and biometric levels the main species of the genus Fusarium associated with onion plants in field in Burkina Faso in order to determine those involved in the major diseases of the crop and develop an appropriate and sustainable management method for these pathogens. 


\section{Material and Methods}

\subsection{Collection, Isolation and Purification of Fusarium Isolates Associated with Onion Plants in Burkina Faso}

Samples of onion plants were collected from 17 onion production sites in Burkina Faso from January to February 2017. The collection sites are located in four onion production zones (Figure 1): the Northern area including Yako, Ouahigouya, Titao, Korsimoro and Kongoussi sites; the Central zone comprising the sites of Mogtédo, Loumbila and Donsin; the Western zone including the sites of Kokologho, Koudougou, Réo, Gassan, Di, Tougan and the South-western area including the sites of Dano, Soumasso and Bama. At each site, samples were collected from three fields separated by at least $5 \mathrm{~km}$, on the basis of ten plants collected at random per field. The isolation of the Fusarium isolates consisted of disinfecting each plant with $3 \%$ sodium hypochlorite and cutting it into small fragments. The fragments were incubated in a Petri dish on moistened blotting paper for five days. Based on the identification manual of fungi [13], plant fragments were examined under a stereo microscope and/or microscope to detect the developing Fusaria, regardless of the species. For each site, the number of Fusarium detected on the incubated onion plants was counted and the results were expressed as a percentage of plants attacked by the fungus. For each type of

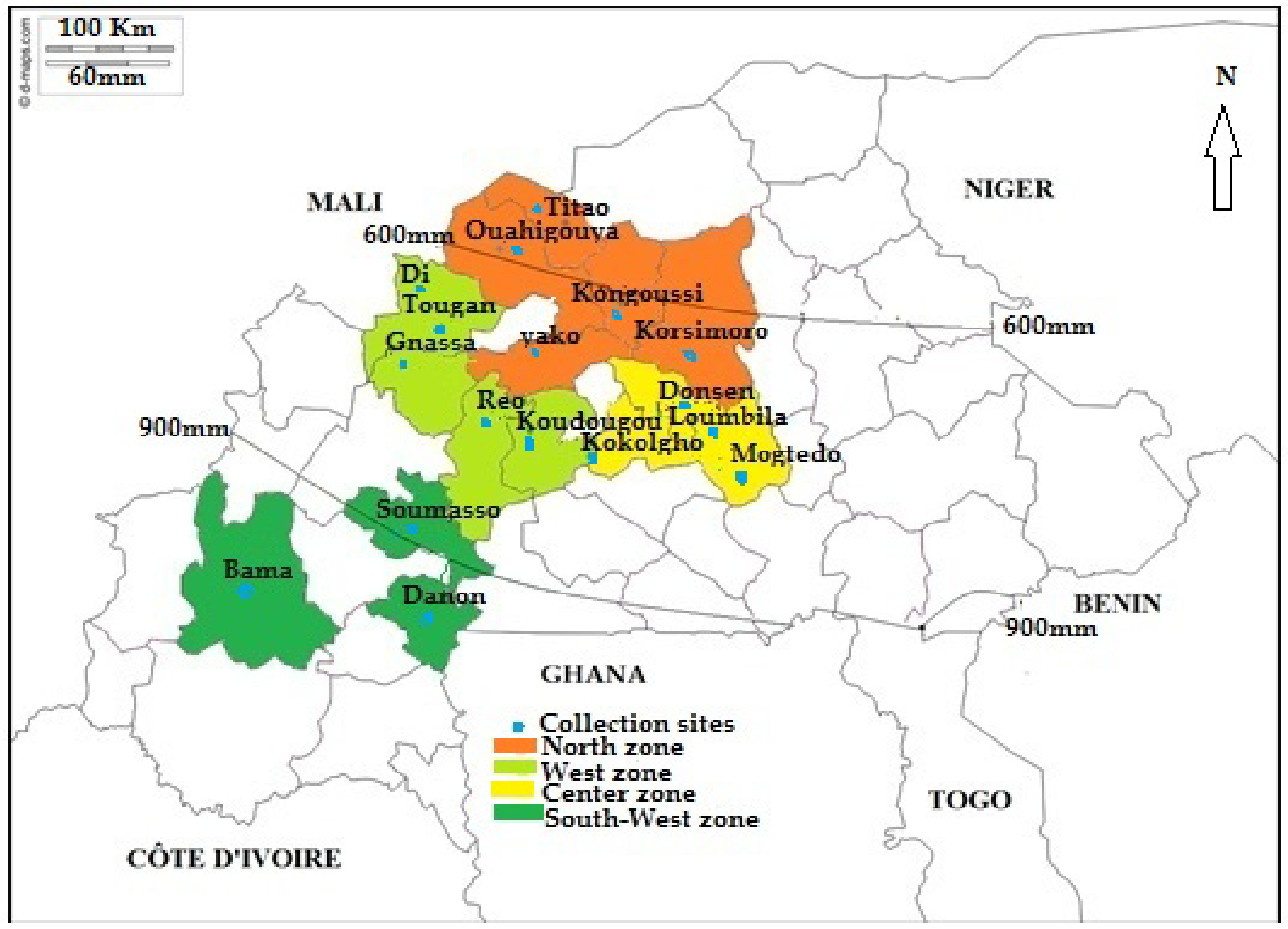

Figure 1. Onion production areas and plant sample collection sites of Allium cepa in 2017. 
Fusarium identified per plant, a small portion of mycelium was aseptically grown in a Petri dish containing PDA (Potato Dextrose Agar) culture medium. Successive transplantation of the isolates into the PDA medium has resulted in pure cultures of these fungi.

\subsection{Molecular Identification of Fusarium Species Associated with Onion Plants in Burkina Faso}

Monosporic cultures were produced from the pure cultures of Fusarium isolates. For each isolate, two drops of conidial suspension containing approximately 100 spores/ml of suspension prepared from a 10 day-old pure culture were spread on an Agar medium contained in a Petri dish. Two days after seeding, the germinating spores were transferred to Petri dishes containing the PDA medium using only one germinating spore per dish, and left to grow. Three monosporic isolates were produced per isolate. Based on the color of the mycelium and/or the shape of the conidia, one to four monosporic isolates were selected per site for molecular analysis.

For fungal DNA extraction, mycelium of the monosporic isolates was first cultured on Potato Dextrose Broth (PDB) liquid medium. For this purpose, a mycelial explant taken from each monosporic isolate in culture on the PDA medium was aseptically deposited in the PDB medium contained in an Erlenmeyer. To stimulate the development of the mycelium in the liquid medium, the bottles were incubated on an oscillator at the speed of 120 oscillations per minute, at room temperature in the laboratory, for two days. After removing the mycelial explant from the Erlenmeyer, the resulting mycelium was collected by filtration using a vacuum pump. For each monosporic isolate, $75 \mathrm{mg}$ of mycelium was collected, transferred to an Eppendorf tube and stored at $-80^{\circ} \mathrm{C}$. The fungal DNA was extracted using the method used by Sadfi-Zouaoui et al. [14] with some modifications. Six hundred microliters $(600 \mu \mathrm{l})$ Cetyl Trimethyl Ammonium Bromide (CTAB) extraction buffer (1.4 M NaCl; $2 \%$ CTAB (w/v); $0.1 \mathrm{M}$ Tris-Base pH8; 0.02 M EDTA pH8; 0.2 B-Mercaptoethanol (v/v)) were added to the $75 \mathrm{mg}$ of mycelium and the mixture was stirred on a vortex for $10 \mathrm{~min}$. The tubes were then placed in a water bath at $65^{\circ} \mathrm{C}$ for $10 \mathrm{~min}$, then $450 \mu \mathrm{l}$ of phenol and $450 \mu \mathrm{l}$ of chloroform alcohol-iso-amyl (composed of $49 \mathrm{ml}$ of chloroform and $1 \mathrm{ml}$ of alcohol-iso-amyl) were added to each tube and then mixed by inversion of the tube until a milky mixture was obtained. After centrifugation at $13,000 \mathrm{~g}$ for five minutes at $25^{\circ} \mathrm{C}$, the supernatant (approximately $500 \mu \mathrm{l}$ ) added to $400 \mu \mathrm{l}$ of alcohol-isoamyl chloroform, was again centrifuged at 13,000 g for two minutes at $25^{\circ} \mathrm{C}$ and then transferred to a new tube by adding 0.7 volume $(300 \mu \mathrm{l})$ cold isopropanol to the solution to precipitate DNA. After a further centrifugation of the mixture, the pellet obtained was rinsed with $500 \mu \mathrm{l}$ of $75 \%$ alcohol and centrifuged for 5 minutes at $13,000 \mathrm{~g}$ at $25^{\circ} \mathrm{C}$, this twice, before being dried in a hood and then dissolved in $50 \mu \mathrm{l}$ of sterile distilled water and stored at $-20^{\circ} \mathrm{C}$. 
The DNA was then determined by spectrophotometer (Nanodrop 2000) and the initial concentration evaluated in nanograms per microliter ( $\mathrm{ng} / \mu \mathrm{l})$. The different concentrations were diluted on a case-by-case basis so that the volume of DNA $(3 \mu \mathrm{l})$ collected for PCR contains about $100 \mathrm{ng}$ of DNA. The amplification reaction was performed in $25 \mu \mathrm{l}$ containing $100 \mathrm{ng}$ DNA $(3 \mu \mathrm{l}) ; 2.5 \mu \mathrm{lD}$ buffer, 10×; $0.5 \mu \mathrm{ldNTP}(10 \mathrm{mM}) ; 2 \mu \mathrm{l} \mathrm{MgCl}(25 \mathrm{mM}) ; 0.2 \mu \mathrm{l}$ Taq polymerase; $15.8 \mu \mathrm{l}$ sterile distilled $\mathrm{H}_{2} \mathrm{O}$ and $0.5 \mu \mathrm{EF} 1$ to $10 \mu \mathrm{M}$ and $\mathrm{EF} 2$ to $10 \mu \mathrm{M}$ primers. The primers used were:

EF1: ATGGGTAAGGARGARGACAAGAC [15];

EF2: GGARGTACCAGTSATCATCATGTT [16].

The amplification reaction was performed according to the following program: a denaturation cycle at $-95^{\circ} \mathrm{C}$ for 10 minutes followed by 35 consecutive cycles (denaturation at $94^{\circ} \mathrm{C}$ for 30 seconds, hybridization at $52^{\circ} \mathrm{C}$ for 30 seconds and elongation at $72^{\circ} \mathrm{C}$ for 45 seconds). The electrophoresis was performed on a $1 \%$ agarose gel at $120 \mathrm{~V}$ for 20 minutes. The amplification products were visualized under UV light, using ethidium bromide previously incorporated into the agarose gel. Thirty microlitres $(30 \mu \mathrm{l})$ of PCR product from each isolate were collected for sequencing.

The sequencing was carried out by Genewiz [17], with the P363 and CHOO9 primers. For the identification of Fusarium species, the sequences were processed, cleaned and aligned with the Chromas software. The consensus sequences obtained were compared with those in the NCBI (National Center for Biotechnologies Information) database on the site [18].

\subsection{Biometric Characterization of Fusarium Species Associated with Onion Plants in Burkina Faso}

In order to determine morphological and cultural characteristics for a good differentiation of Fusarium species isolated from onion plants, three biometric characteristics related to the colony growth in culture, the conidia sizes and the number of cells (or divisions) per conidia were evaluated.

The experimental design used is a randomized complete block design with four replications. To assess the mycelial growth of the colonies, the diameter of the colonies was measured in each dish on the ninth (9th) day after the incubation of the explants in the PDA medium. The result, expressed in millimeters, was the average of two diameters perpendicular to each other.

The mycelial growth rate was calculated according to the formula:

$$
V=[(D 1-4)+(D 2-4)] / N \times 2
$$

where $V=$ Growth rate of the fungus in $\mathrm{mm} /$ day; $D 1$ and $D 2$ are the two perpendicular diameters of the colony, $N$ the number of days after transplanting the explant and 4 the diameter of the explants.

For the evaluation of conidial dimensions, 25 conidia were randomly selected per monosporic isolate (one conidia representing a repetition), the length and width of each conidia were measured. The evaluation of the number of cells per 
conidia was coupled with the conidia size evaluation. The number of cells in each conidium was determined by counting the number of subdivisions within that conidium.

The biometric data collected were subjected to an analysis of variance using the Statistical Analysis System (SAS) software, version 8; 2001. The calculation and separation of the means of the measured parameters were performed according to the Duncan test (Duncan Range Multiple Test), at the 1\% threshold.

\section{Results}

\subsection{Prevalence of Fungi of the Genus Fusarium on Onion Plants in Different Growing Sites in Burkina Faso}

A total of 510 onion plant samples were collected from the 17 production sites. Visual examination of these incubated plant samples allowed the detection and isolation of several types of Fusarium associated with the plants. The results of the analysis of variance showed that the prevalence of fungi of the genus Fusarium varied widely ( $\mathrm{p}<0.0001)$ depending on the collection sites (Table 1$)$. The fungus was present in all onion growing sites where it infected $10 \%$ to $90 \%$ of the sampled plants with an average attack rate of $62.55 \%$. The sites studied were classified into four distinct groups: Group 1, composed of nine (9) sites (Yako,

Table 1. Prevalence of Fusarium spp. On onion fields in different production sites in Burkina Faso.

\begin{tabular}{cc}
\hline Samples collection sites & Percentage of onion plants infected by Fusarium spp \\
\hline Yako (Yk) & $90.00 \mathrm{a}$ \\
Titao (T) & $86.67 \mathrm{a}$ \\
Gassan (Ga) & $83.33 \mathrm{a}$ \\
Di (Di) & $80.00 \mathrm{a}$ \\
Kongoussi (Kg) & $80.00 \mathrm{a}$ \\
Korsimoro (Kr) & $76.67 \mathrm{a}$ \\
Mogtedo (Mg) & $76.67 \mathrm{a}$ \\
Dano (Da) & $73.33 \mathrm{a}$ \\
Reo (R.) & $66.67 \mathrm{a}$ \\
Loumbila (Lm) & $63.33 \mathrm{ab}$ \\
Ouayigouya (Oua) & $63.33 \mathrm{ab}$ \\
Donsin (Do) & $60.00 \mathrm{ab}$ \\
Koudougou & $56.67 \mathrm{ab}$ \\
Kokologho & $53.33 \mathrm{ab}$ \\
Tougan & $30.00 \mathrm{bc}$ \\
Soumasso & $13.30 \mathrm{c}$ \\
Bama & $10.00 \mathrm{c}$ \\
Average & 62.55 \\
CV (\%) & 29.70 \\
P value & $<0.0001$ \\
\hline
\end{tabular}

The values of the same column assigned the same alphabetical letter(s) are not significantly $5 \%$ threshold, according to the Duncan test. 
Titao, Gassan, Di, Kongoussi, Korsimoro, Mogtédo, Dano and Réo), with the highest attack rates ranging from $66.67 \%$ to $90 \%$. The second group includes the sites of Loumbila, Ouahigouya, Donsin, Koudougou and Kokologho, with 53.33\% to $63.33 \%$ of contaminated plants. The third group includes a single site (Tougan) with a low prevalence rate of $30 \%$. Finally, the fourth group includes the sites of Bama and Soumasso where the prevalence of Fusarium on plants was very low (10\% - 13.33\% of infected plants). Considering the onion production areas, the results also indicated that the prevalence of Fusarium was significantly higher $(\mathrm{p}=0.0004)$ in the northern, western and central zones of the country than in the southwestern zone (Table 2).

Table 2. Prevalence of Fusarium spp. on onion plants in different geographical zones in Burkina Faso.

\begin{tabular}{cc}
\hline Onion production areas & Percentage of onion plants infected by Fusarium spp. \\
\hline North Zone & $79.33 \mathrm{a}$ \\
West Zone & $61.67 \mathrm{a}$ \\
Central Zone & $66.67 \mathrm{a}$ \\
Southwest Zone & $32.22 \mathrm{~b}$ \\
Average & 62.54 \\
CV (\%) & 38.24 \\
P value & 0,0004 \\
\hline
\end{tabular}

\subsection{The Main Fusarium Species Associated with Onion Plants in Burkina Faso}

Based on the color of the mycelium, the shape and/or the size of the conidia, thirty-six monosporic isolates were selected for molecular analysis. Chromatography results obtained on agarose gel using the primers EF1 and EF2 indicated that the molecular weights of the different products are approximately $700 \mathrm{bp}$ for all isolates (Figure 2), indicating that these isolates are indeed fungi belonging to the genus Fusarium.

Analysis of the obtained sequences and their comparison with the sequences in the NCBI database revealed $99 \%$ of identity for 26 isolates, $98 \%$ for five isolates, $97 \%$ for four isolates and $93 \%$ for one isolate (Table 3). The analysis showed that the isolates belong to five species of Fusarium:

- Fusarium oxysporum which includes 16 isolates (44.44\% of the studied isolates) with similarity rates of $93 \%$ - 99\% with the reference accessions JF957830.1, KU985430.1 and JF957820.1 of the NCBI.

- Fusarium proliferatum which includes 15 isolates (41.66\%) with $99 \%$ similarity rates to the NCBI reference accession KF222556.1.

- Fusarium solani which includes two isolates (5.55\%) with 99\% similarity rates to NCBI reference accessions KY486699.1 and KR816154.1.

- Fusarium fujikuroi which also includes two isolates (5.55\%) with similarity rates of $97 \%$ to the NCBI reference accession LC055826.1.

- Fusarium thapsinum which comprises a single isolate (2.77\%) with a $99 \%$ similarity rate to the NCBI reference accession KU508368.1. 
Table 3. Comparisons of sequences of Fusarium isolates collected from onion plants in Burkina Faso with sequences available in the NCBI database.

\begin{tabular}{|c|c|c|c|c|c|c|}
\hline ISOLATS & $\begin{array}{l}\text { Consensus } \\
\text { sequence } \\
\text { size }(b p)\end{array}$ & $\begin{array}{l}\text { Species } \\
\text { accession } \\
\text { number }\end{array}$ & Corresponding species in the NCBI database & $\begin{array}{l}\text { Loci } \\
\text { (bp) }\end{array}$ & $\begin{array}{l}\text { Identity } \\
(\%)\end{array}$ & $\begin{array}{l}\text { Query } \\
\text { cover } \\
(\%)\end{array}$ \\
\hline F.o-16-Ba & 710 & JF957830.1 & $\begin{array}{l}\text { Fusarium oxysporum } f . s p . \text { carthami isolate EF1-70RD } \\
\text { translation enlongation factor } 1 \text {-alpha }(E F 1-a) \text { gene partial } \\
\text { sequence }\end{array}$ & 714 & 99 & 91 \\
\hline F.pro-31-Ba & 672 & KF222556.1 & $\begin{array}{l}\text { Fusarium proliferatum isolate fus } 11 \text { translation elongation } \\
\text { factor } 1 \text { alpha gene, partial cds }\end{array}$ & 672 & 99 & 98 \\
\hline F.o-49-Da & 615 & KU985430.1 & $\begin{array}{l}\text { Fusarium oxysporum isolate EKT } 01 \text { translation elongation } \\
\text { factor } 1 \text {-alpha (TEF1) gene, partial cds }\end{array}$ & 703 & 99 & 94 \\
\hline F.o-42-Di & 710 & JF957830.1 & $\begin{array}{l}\text { Fusarium oxysporum } f . s p . \text { carthami isolate } E F 1-70 R D \\
\text { translation enlongation factor } 1 \text {-alpha }(E F 1-a) \text { gene partial } \\
\text { sequence }\end{array}$ & 714 & 99 & 92 \\
\hline F.pro-21-Do & 672 & KF222556.1 & $\begin{array}{l}\text { Fusarium proliferatum isolate fus } 11 \text { translation elongation } \\
\text { factor } 1 \text { alpha gene, partial cds }\end{array}$ & 672 & 99 & 98 \\
\hline F.pro-14-Ga & 672 & KF222556.1 & $\begin{array}{l}\text { Fusarium proliferatum isolate fus } 11 \text { translation elongation } \\
\text { factor } 1 \text { alpha gene, partial cds }\end{array}$ & 672 & 99 & 98 \\
\hline F.pro-1-Ga & 672 & KF222556.1 & $\begin{array}{l}\text { Fusarium proliferatum isolate fus } 11 \text { translation elongation } \\
\text { factor } 1 \text { alpha gene, partial cds }\end{array}$ & 672 & 99 & 98 \\
\hline F.fujik-2-Ga & 662 & LC055826.1 & $\begin{array}{l}\text { Fusarium cf. fujikuroi IPBCC } 14.1236 \text { DNA, translation } \\
\text { elongation factor } 1 \text { apha, partial sequence, strain: IPBCC } \\
14.1236\end{array}$ & 663 & 97 & 94 \\
\hline F.o-61-Kd & 710 & JF957830.1 & $\begin{array}{l}\text { Fusarium oxysporum } f \text {. sp. carthami isolate } E F 1-70 R D \\
\text { translation enlongation factor } 1 \text {-alpha }(E F 1-a) \text { gene } \\
\text { partial sequence }\end{array}$ & 714 & 98 & 95 \\
\hline F.o-60-Kd & 710 & JF957820.1 & $\begin{array}{l}\text { Fusarium oxysporum } f . \text { sp. carthami isolate } E F 1-5 R D \\
\text { translation enlongation factor } 1 \text {-alpha }(E F 1-a) \text { gene, } \\
\text { partial sequence }\end{array}$ & 730 & 98 & 92 \\
\hline F.o-50-Kg & 710 & JF957830.1 & $\begin{array}{l}\text { Fusarium oxysporum } f . s p . \text { carthami isolate } E F 1-70 R D \\
\text { translation enlongation factor } 1 \text {-alpha }(E F 1-a) \\
\text { gene partial sequence }\end{array}$ & 714 & 99 & 92 \\
\hline F.o-52-Kg & 626 & KU985430.1 & $\begin{array}{l}\text { Fusarium oxysporum isolate EKT } 01 \text { translation elongation } \\
\text { factor 1-alpha (TEF1) gene, partial cds }\end{array}$ & 703 & $97 \%$ & $92 \%$ \\
\hline F.s-24-Kk & 706 & KR816154.1 & $\begin{array}{l}\text { Fusarium_solani_isolate_ML06_translation_elongation_ } \\
\text { factor_1-alpha_(tef)_gene_partial_cds }\end{array}$ & 716 & $99 \%$ & $94 \%$ \\
\hline F.pro-19-Kr & 672 & KF222556.1 & $\begin{array}{l}\text { Fusarium proliferatum isolate fus } 11 \text { translation elongation } \\
\text { factor } 1 \text { alpha gene, partial cds }\end{array}$ & 672 & $99 \%$ & $98 \%$ \\
\hline F.o-63-Kr & 710 & JF957830.1 & $\begin{array}{l}\text { Fusarium oxysporum } \mathrm{f} \text {. sp. carthami isolate EF1-70RD } \\
\text { translation enlongation factor 1-alpha (EF1-a) } \\
\text { gene partial sequence }\end{array}$ & 714 & $99 \%$ & $94 \%$ \\
\hline F.pro-18-Kr & 672 & KF222556.1 & $\begin{array}{l}\text { Fusarium proliferatum isolate fus } 11 \text { translation elongation } \\
\text { factor } 1 \text { alpha gene, partial cds }\end{array}$ & 672 & $99 \%$ & $98 \%$ \\
\hline F.pro-17-Kr & 672 & KF222556.1 & $\begin{array}{l}\text { Fusarium proliferatum isolate fus } 11 \text { translation elongation } \\
\text { factor } 1 \text { alpha gene, partial cds }\end{array}$ & 672 & $99 \%$ & $98 \%$ \\
\hline
\end{tabular}




\section{Continued}

\begin{tabular}{|c|c|c|c|c|c|c|}
\hline F.o-7-Lm & 626 & KU985430.1 & $\begin{array}{l}\text { Fusarium oxysporum isolate EKT } 01 \text { translation elongation } \\
\text { factor 1-alpha (TEF1) gene, partial cds }\end{array}$ & 703 & $99 \%$ & $96 \%$ \\
\hline F.o-9-Lm & 710 & JF957830.1 & $\begin{array}{l}\text { Fusarium oxysporum } \mathrm{f} \text {. sp. carthami isolate EF1-70RD } \\
\text { translation enlongation factor 1-alpha (EF1-a) } \\
\text { gene partial sequence }\end{array}$ & 714 & $98 \%$ & $94 \%$ \\
\hline F.o-8-Lm & 710 & JF957830.1 & $\begin{array}{l}\text { Fusarium oxysporum } \mathrm{f} \text {. sp. carthami isolate EF1-70RD } \\
\text { translation enlongation factor 1-alpha (EF1-a) } \\
\text { gene partial sequence }\end{array}$ & 714 & $93 \%$ & $93 \%$ \\
\hline $\begin{array}{c}\text { F. } \\
\text { fujik-27-Mt }\end{array}$ & 662 & LC055826.1 & $\begin{array}{l}\text { Fusarium cf. fujikuroi IPBCC } 14.1236 \text { DNA, translation } \\
\text { elongation factor } 1 \text { apha, partial sequence, strain: IPBCC } \\
14.1236\end{array}$ & 663 & $97 \%$ & $94 \%$ \\
\hline F.pro-29-Mt & 672 & KF222556.1 & $\begin{array}{l}\text { Fusarium proliferatum isolate fus } 11 \text { translation elongation } \\
\text { factor } 1 \text { alpha gene, partial cds }\end{array}$ & 672 & $99 \%$ & $98 \%$ \\
\hline F.o-67-Mt & 626 & KU985430.1 & $\begin{array}{l}\text { Fusarium oxysporum isolate EKT } 01 \text { translation elongation } \\
\text { factor } 1 \text {-alpha (TEF1) gene, partial cds }\end{array}$ & 703 & $97 \%$ & $92 \%$ \\
\hline F.thap-35-Ou & 649 & KU508368.1 & $\begin{array}{l}\text { Fusarium thapsinum strain T1.13 translation elongation } \\
\text { factor } 1 \text {-alpha (EF1-alpha) gene, partial cds }\end{array}$ & 653 & $99 \%$ & $95 \%$ \\
\hline F.pro-37-Ou & 672 & KF222556.1 & $\begin{array}{l}\text { Fusarium proliferatum isolate fus } 11 \text { translation elongation } \\
\text { factor } 1 \text { alpha gene, partial cds }\end{array}$ & 672 & $99 \%$ & $98 \%$ \\
\hline F.pro-15-R & 672 & KF222556.1 & $\begin{array}{l}\text { Fusarium proliferatum isolate fus } 11 \text { translation elongation } \\
\text { factor } 1 \text { alpha gene, partial cds }\end{array}$ & 672 & $99 \%$ & $98 \%$ \\
\hline F.pro-11-R & 672 & KF222556.1 & $\begin{array}{l}\text { Fusarium proliferatum isolate fus } 11 \text { translation elongation } \\
\text { factor } 1 \text { alpha gene, partial cds }\end{array}$ & 672 & $99 \%$ & $98 \%$ \\
\hline F.pro-3-Sm & 672 & KF222556.1 & $\begin{array}{l}\text { Fusarium proliferatum isolate fus } 11 \text { translation elongation } \\
\text { factor } 1 \text { alpha gene, partial cds }\end{array}$ & 672 & $99 \%$ & $98 \%$ \\
\hline F.o-5-Sm & 710 & JF957820.1 & $\begin{array}{l}\text { Fusarium oxysporum f. sp. carthami isolate EF1-5RD } \\
\text { translation elongation factor 1-alpha }(E F 1-a) \\
\text { gene, partial sequence }\end{array}$ & 730 & $98 \%$ & $92 \%$ \\
\hline F.pro-4-Sm & 672 & KF222556.1 & $\begin{array}{l}\text { Fusarium proliferatum isolate fus } 11 \text { translation elongation } \\
\text { factor } 1 \text { alpha gene, partial cds }\end{array}$ & 672 & $99 \%$ & $98 \%$ \\
\hline F.o-66-Sm & 710 & JF957830.1 & $\begin{array}{l}\text { Fusarium oxysporum } f . s p . \text { carthami isolate } E F 1-70 R D \\
\text { translation enlongation factor } 1 \text {-alpha }(E F 1-a) \\
\text { gene partial sequence }\end{array}$ & 714 & $98 \%$ & $95 \%$ \\
\hline F.pro-33-Tm & 672 & KF222556.1 & $\begin{array}{l}\text { Fusarium proliferatum isolate fus } 11 \text { translation elongation } \\
\text { factor } 1 \text { alpha gene, partial cds }\end{array}$ & 672 & $99 \%$ & $98 \%$ \\
\hline F.pro-32-Tm & 672 & KF222556.1 & $\begin{array}{l}\text { Fusarium proliferatum isolate fus } 11 \text { translation elongation } \\
\text { factor } 1 \text { alpha gene, partial cds }\end{array}$ & 672 & $99 \%$ & $98 \%$ \\
\hline F.s-38-Tg & 712 & KY486699.1 & $\begin{array}{l}\text { Fusarium solani isolate } \mathrm{CH}-3 \mathrm{P} \text { translation elongation factor } \\
\text { 1-alpha (tefl) gene, partial } c d s\end{array}$ & 716 & $99 \%$ & $100 \%$ \\
\hline F.o-58-Yk & 684 & JF957830.1 & $\begin{array}{l}\text { Fusarium oxysporum } f \text {. sp. carthami isolate } E F 1-70 R D \text { gène } \\
\text { d'allongement de la traduction facteur 1-alpha }(E F 1-a) \text {, } \\
\text { séquence partielle }\end{array}$ & 714 & $99 \%$ & $96 \%$ \\
\hline F.o-59-YK & 630 & KU985430.1 & Fusarium oxysporum isolate EKT 01 & 703 & $99 \%$ & $98 \%$ \\
\hline
\end{tabular}

F. $\mathrm{o}=$ Fusarium oxysporum; F. pro $=$ Fusarium proliferatum; F. fujk $=$ Fusarium fujikuroi; F. $\mathrm{s}=$ Fusarium solani; F. thap $=$ Fusarium thapsinum. Yk $=$ Yako; $\mathrm{T}=$ Titao; $\mathrm{Ga}=$ Gassan; $\mathrm{Di} ; \mathrm{Kg}=$ Kongoussi $\mathrm{K} \mathrm{r}=$ Korsimoro; $\mathrm{Mg}=$ Mogtedo; $\mathrm{Da}=$ Dano; $\mathrm{R}=\mathrm{Reo} ; \mathrm{Lm}=$ Loumbila Oua $=$ Ouayigouya; $\mathrm{Do}=$ Donsin; $\mathrm{Kd}$ = Koudougou; $\mathrm{Kk}$ = Kokologho; $\mathrm{Tg}$ = Tougan; $\mathrm{Sm}$ = Soumasso; $\mathrm{Ba}=$ Bama. 


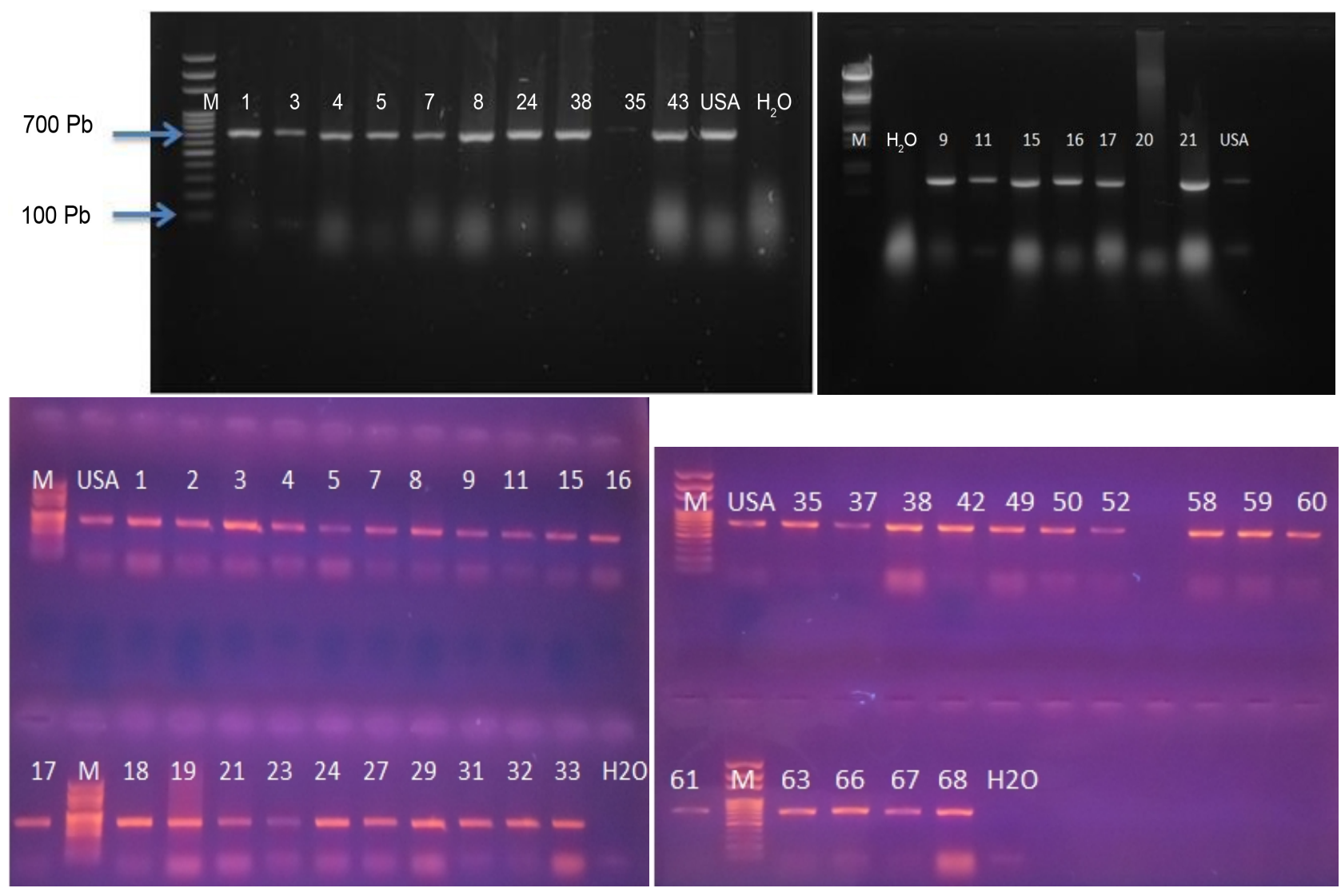

Figure 2. Migration of PCR products from the amplification of EF1 and EF2 elongation factors of some single-pore Fusarium isolates (KINTEGA, 2018) 1, 2, 3, $4 \ldots$ number of isolates whose DNA was used for PCR.

\subsection{Biometric Characteristics of the Main Fusarium Species Identified on Onion Plants in Burkina Faso}

The analysis of variance performed on biometric data including the mycelial growth speed of fungi, the length and diameter of conidia, the number of cells per conidium, revealed significant differences between the Fusarium species. In general, F. oxysporum, F. proliferatum, F. solani and F. fujikuroi had rapid mycelial development $(7.72-8.27 \mathrm{~mm} / \mathrm{d})$ on the PDA culture medium compared to $F$. thapsinum which had slow growth $(6.52 \mathrm{~mm} / \mathrm{d})$ (Table 4$)$. The conidia of F. oxysporum, F. proliferatum and $F$. solani were relatively longer $(4.74-5.96 \mu \mathrm{m})$ than those of $F$. fujikuroi $(3.20 \mu \mathrm{m})$ and $F$. thapsinum $(4.04$ $\mu \mathrm{m})$. Of the five species, $F$. solani had the largest conidia (1.88 $\mu \mathrm{m}$ wide) while $F$. oxysporum had the conidia with the highest number of cells per conidium (1.94). The results also showed variability between isolates within the same species. Indeed, 12 isolates belonging to the species F. oxysporum (i.e. $75 \%$ of the population) grew fast $(7.88-9 \mathrm{~mm} / \mathrm{d})$ against four isolates (i.e. $25 \%)$ with slow growth $(6.72-7.33 \mathrm{~mm} / \mathrm{d})$ (Table 5). Among the fast-growing isolates, F.o-8-Lm and F.o-60-Kd presented long (12.28 - 17.24 $\mu \mathrm{m})$ and large (1.92 - 3.96 $\mu \mathrm{m})$ conidia with more than three cells per conidium $(3.40-5.80$ cells per conidium). All other isolates of this species showed small conidia $(2.52-10 \mu \mathrm{m} \times$ $1-2 \mu \mathrm{m}$ ) with 1 to 2.48 cells per conidium (Table 5). 
Table 4. Bio-morphological characteristics of five Fusarium species associated with onion in the field.

\begin{tabular}{lcccc}
\hline \multicolumn{1}{c}{$\begin{array}{c}\text { Fusarium } \\
\text { species }\end{array}$} & $\begin{array}{c}\text { Mycelial growth } \\
\text { speed }(\mathrm{mm} / \mathrm{d})\end{array}$ & $\begin{array}{c}\text { Number of } \\
\text { cells/conidium }\end{array}$ & $\begin{array}{c}\text { Conidia } \\
\text { Width }(\mu \mathrm{m})\end{array}$ & $\begin{array}{c}\text { Conidia } \\
\text { Length }(\mu \mathrm{m})\end{array}$ \\
\hline $\begin{array}{l}\text { F. proliferatum } \\
\text { F. oxysporum }\end{array}$ & $8.31 \mathrm{a}$ & $1.49 \mathrm{~b}$ & $1.11 \mathrm{~b}$ & $5.29 \mathrm{ab}$ \\
F. solani & $8.27 \mathrm{a}$ & $1.94 \mathrm{a}$ & $1.32 \mathrm{~b}$ & $5.96 \mathrm{a}$ \\
F. fujikuroï & $7.72 \mathrm{a}$ & $1.42 \mathrm{~b}$ & $1.88 \mathrm{a}$ & $4.74 \mathrm{abc}$ \\
F. thapsinum & $7.90 \mathrm{a}$ & $1.04 \mathrm{~b}$ & $1.02 \mathrm{~b}$ & $3.20 \mathrm{c}$ \\
Average & $6.52 \mathrm{~b}$ & $1.24 \mathrm{~b}$ & $1.12 \mathrm{~b}$ & $4.04 \mathrm{bc}$ \\
$\begin{array}{l}\text { Standard } \\
\text { deviation }\end{array}$ & 8.19 & 1.65 & 1.25 & 5.41 \\
p value & 0.13 & 0.05 & 0.02 & 0.02 \\
\hline
\end{tabular}

Table 5. Mycelial growth speed, dimensions of the conidia and number of cells per conidia of 16 isolates of Fusarium oxysporum associated with onions in the field in Burkina Faso.

\begin{tabular}{|c|c|c|c|c|}
\hline $\begin{array}{l}\text { F. oxysporum } \\
\text { Isolats }\end{array}$ & $\begin{array}{l}\text { Mycelial growth } \\
\text { speed }(\mathrm{mm} / \mathrm{d})\end{array}$ & $\begin{array}{c}\text { Number of } \\
\text { cells/conidium }\end{array}$ & $\begin{array}{c}\text { Conidia } \\
\text { width }(\mu \mathrm{m})\end{array}$ & $\begin{array}{c}\text { Conidia } \\
\text { length }(\mu \mathrm{m})\end{array}$ \\
\hline F.o-8-Lm & $9.00 \mathrm{a}$ & $5.80 \mathrm{a}$ & $3.96 a$ & $17.24 \mathrm{a}$ \\
\hline F.o-63-Kr & $9.00 \mathrm{a}$ & $1.00 \mathrm{~g}$ & $1.00 \mathrm{~b}$ & $3.24 \mathrm{ef}$ \\
\hline F.o-5-Sm & $9.00 \mathrm{a}$ & $2.08 \mathrm{de}$ & $1.00 \mathrm{~b}$ & $6.43 \mathrm{~d}$ \\
\hline F.o-66-Sm & $9.00 \mathrm{a}$ & $1.68 \mathrm{ef}$ & $1.00 \mathrm{~b}$ & $5.32 \mathrm{de}$ \\
\hline F.o-61-Kd & $9.00 \mathrm{a}$ & $2.44 \mathrm{c}$ & $2.00 \mathrm{~b}$ & $10.00 c$ \\
\hline F.o-16-Ba & $8.95 \mathrm{ab}$ & $1.00 \mathrm{~g}$ & $1.00 \mathrm{~b}$ & $2.52 \mathrm{f}$ \\
\hline F.o-60-Kd & $8.80 \mathrm{bc}$ & $3.28 b$ & $1.92 \mathrm{~b}$ & $12.28 \mathrm{~b}$ \\
\hline F.o-49-Da & $8.66 c$ & $1.12 \mathrm{~g}$ & $1.00 \mathrm{~b}$ & $3.00 \mathrm{ef}$ \\
\hline F.o-59-Yk & $8.37 \mathrm{~d}$ & $1.32 \mathrm{fg}$ & $1.28 \mathrm{~b}$ & $3.84 \mathrm{ef}$ \\
\hline F.o-42-Di & $8.12 \mathrm{e}$ & $1.00 \mathrm{~g}$ & $1.00 \mathrm{~b}$ & $3.24 \mathrm{ef}$ \\
\hline F.o-67-Mt & $8.00 \mathrm{ef}$ & $1.72 \mathrm{ef}$ & $1.00 \mathrm{~b}$ & $5.12 \mathrm{de}$ \\
\hline F.o-58-Yk & $7.88 \mathrm{f}$ & $1.00 \mathrm{~g}$ & $1.00 \mathrm{~b}$ & $3.12 \mathrm{ef}$ \\
\hline F.o-52-Kg & $7.33 \mathrm{~g}$ & $2.24 \mathrm{~cd}$ & $1.00 \mathrm{~b}$ & $3.88 \mathrm{ef}$ \\
\hline F.o-7-Lm & $7.33 \mathrm{~g}$ & $2.48 \mathrm{~cd}$ & $1.00 \mathrm{~b}$ & $9.64 c$ \\
\hline F.o-50-Kg & $7.16 \mathrm{~h}$ & $1.36 \mathrm{fg}$ & $1.08 \mathrm{~b}$ & $3.44 \mathrm{ef}$ \\
\hline F.o-9-Lm & $6.72 \mathrm{i}$ & $1.00 \mathrm{~g}$ & $1.00 \mathrm{~b}$ & $3.24 \mathrm{ef}$ \\
\hline Average & 8.27 & 1.94 & 1.32 & 5.96 \\
\hline $\begin{array}{l}\text { Standard } \\
\text { deviation }\end{array}$ & 0.98 & 0.74 & 0.16 & 0.56 \\
\hline$P$ value & $<0.0001$ & $<0.0001$ & $<0.0001$ & $<0.0001$ \\
\hline
\end{tabular}


In the F. proliferatum species, 12 isolates (i.e. $80 \%)$ grew rapidly (7.86 - 9 $\mathrm{mm} / \mathrm{d}$ ) against three isolates (i.e. 20\%) with slow growth (Table 6). Among the fast-growing isolates, F.pro-4-Sm; F.pro-15-R; F.pro-3-Sm produced long conidia $(9.44-11.24 \mu \mathrm{m})$ with 2.60 to 2.96 cells each (Table 6). In contrast, the other isolates had small conidia.

F. fujikuroi included two isolates, one fast-growing $(8.98 \mathrm{~mm} / \mathrm{d})$ and the other slow-growing $(6.81 \mathrm{~mm} / \mathrm{d})$. For the other characteristics, no significant differences were noted between these two isolates (Table 7). In F. solani, the isolate F. s-38-Tg was characterized by a rapid growth rate $(9 \mathrm{~mm} / \mathrm{d})$ and large conidia ( 2 $\mu \mathrm{m}$ wide) and the isolate F. s-24-Kk by a slow growth of $6.45 \mathrm{~mm} / \mathrm{d}$ and fine conidia $(1.76 \mu \mathrm{m}$ wide).

Table 6. Mycelial growth speed, size of conidia and number of cells per conidia of 15 isolates of Fusarium proliferatum associated with onions in the field in Burkina Faso.

\begin{tabular}{|c|c|c|c|c|}
\hline $\begin{array}{l}\text { F. proliferatum } \\
\text { isolats }\end{array}$ & $\begin{array}{c}\text { Mycelial } \\
\text { growth speed } \\
(\mathrm{mm} / \mathrm{d})\end{array}$ & $\begin{array}{c}\text { Number of } \\
\text { cells/conidium }\end{array}$ & $\begin{array}{c}\text { Conidia } \\
\text { width }(\mu \mathrm{m})\end{array}$ & $\begin{array}{c}\text { Conidia } \\
\text { length }(\mu \mathrm{m})\end{array}$ \\
\hline F.pro-32-Tm & $9.00 \mathrm{a}$ & $1.52 \mathrm{bc}$ & $1.00 \mathrm{c}$ & $4.92 \mathrm{~cd}$ \\
\hline F.pro-3-Sm & $9.00 \mathrm{a}$ & $2.68 \mathrm{a}$ & $1.00 \mathrm{c}$ & $9.44 \mathrm{ab}$ \\
\hline F.pro-15-R & $9.00 \mathrm{a}$ & $2.60 \mathrm{a}$ & $1.96 \mathrm{a}$ & $10.88 \mathrm{a}$ \\
\hline F.pro-31-Ba & $8.98 \mathrm{a}$ & $1.36 \mathrm{bc}$ & $1.08 \mathrm{~b}$ & $3.56 \mathrm{cde}$ \\
\hline F.pro-33-Tm & $8.97 \mathrm{a}$ & $1.56 \mathrm{~b}$ & $1.00 \mathrm{c}$ & $5.28 \mathrm{c}$ \\
\hline F.pro-37-Ou & $8.81 \mathrm{ab}$ & $1.00 \mathrm{c}$ & $1.04 \mathrm{bc}$ & $3.96 \mathrm{cde}$ \\
\hline F.pro-19-Kr & $8.79 \mathrm{ab}$ & $1.08 \mathrm{c}$ & $2.00 \mathrm{a}$ & $8.00 \mathrm{~b}$ \\
\hline F.pro-4-Sm & $8.44 \mathrm{bc}$ & $2.96 \mathrm{a}$ & $1.00 \mathrm{c}$ & $11.24 \mathrm{a}$ \\
\hline F.pro-11-R & $8.40 \mathrm{bc}$ & $1.00 \mathrm{c}$ & $1.00 \mathrm{c}$ & $3.88 \mathrm{cde}$ \\
\hline F.pro-18-Kr & $8.29 \mathrm{bcd}$ & $1.00 \mathrm{c}$ & $1.00 \mathrm{c}$ & $2.88 \mathrm{de}$ \\
\hline F.pro-29-Mt & $7.9583 \mathrm{~cd}$ & $1.04 \mathrm{c}$ & $1.00 \mathrm{c}$ & 4.44cde \\
\hline F.pro-21-Do & $7.8611 \mathrm{~d}$ & $1.00 \mathrm{c}$ & $1.00 c$ & $3.52 \mathrm{cde}$ \\
\hline F.pro-17-Kr & $7.2917 \mathrm{e}$ & $1.00 \mathrm{c}$ & $1.00 \mathrm{c}$ & $2.52 \mathrm{e}$ \\
\hline F.pro-14-Ga & $7.19 \mathrm{ef}$ & $1.00 \mathrm{c}$ & $1.00 \mathrm{c}$ & $2.68 \mathrm{de}$ \\
\hline F.pro-1-Ga & $6.77 \mathrm{f}$ & $1.00 \mathrm{c}$ & $1.00 \mathrm{c}$ & $2.24 \mathrm{e}$ \\
\hline Average & 8.31 & 0.16 & 1.13 & 5.29 \\
\hline $\begin{array}{l}\text { Standard } \\
\text { deviation }\end{array}$ & 0.85 & 0.42 & 0.91 & 0.42 \\
\hline$P$ value & $<0.0001$ & $<0.0001$ & $<0.0001$ & $<0.0001$ \\
\hline
\end{tabular}


Table 7. Mycelial growth speed, conidial dimensions and number of cells per conidia of two isolates of Fusarium solani and two isolates of F. fujikurö̈ associated with onions in the field in Burkina Faso.

\begin{tabular}{|c|c|c|c|c|}
\hline $\begin{array}{l}\text { Isolats of } \\
\text { Fusarium }\end{array}$ & $\begin{array}{l}\text { Mycelial growth } \\
\text { speed }(\mathrm{mm} / \mathrm{d})\end{array}$ & $\begin{array}{l}\text { Number of } \\
\text { cells/conidia }\end{array}$ & $\begin{array}{c}\text { Width of } \\
\text { conidia }(\mu \mathrm{m})\end{array}$ & $\begin{array}{c}\text { Length of } \\
\text { conidia }(\mu \mathrm{m})\end{array}$ \\
\hline \multicolumn{5}{|c|}{ Fusarium solani } \\
\hline F.s-38-Tg & $9.00 \mathrm{a}$ & $1.36 \mathrm{a}$ & $2.00 \mathrm{a}$ & $4.76 \mathrm{a}$ \\
\hline F.s-24-Kk & $6.45 b$ & $1.44 \mathrm{a}$ & $1.76 \mathrm{~b}$ & $4.72 \mathrm{a}$ \\
\hline Average & 7.72 & 1.4 & 1.88 & 4.74 \\
\hline $\begin{array}{l}\text { Standard } \\
\text { deviation }\end{array}$ & 0.98 & 0.006 & 0.136 & 0.0002 \\
\hline $\mathrm{P}$ & $<0.0001$ & 0.7799 & 0.0083 & 0.9056 \\
\hline \multicolumn{5}{|c|}{ Fusarium fujikuroi } \\
\hline F.fujik-2-Ga & $6.81 \mathrm{~b}$ & $1.08 \mathrm{a}$ & $1.00 \mathrm{a}$ & $3.36 \mathrm{a}$ \\
\hline F. fujik-27-Mt & $8.98 \mathrm{a}$ & $1.00 \mathrm{a}$ & $1.04 \mathrm{a}$ & $3.04 \mathrm{a}$ \\
\hline Average & 7.90 & 1.04 & 3.20 & 1.02 \\
\hline $\begin{array}{l}\text { Standard } \\
\text { deviation }\end{array}$ & 0.99 & 0.04 & 0.02 & 0.02 \\
\hline $\mathrm{P}$ & $<0.0001$ & 0.1551 & 0.2946 & 0.3223 \\
\hline
\end{tabular}

The values of the same column assigned the same alphabetical letter(s) are not significantly $5 \%$ threshold, according to the Duncan test.

\section{Discussion}

The results of the analysis of the onion plants sampled in seventeen onion growing sites in Burkina Faso has allowed to note the presence of fungi of the genus Fusarium in these sites and to classify these sites into three categories according to the proportions of plants contaminated by these fungi. Fusarium was found in all the studied sites, indicating that the fungus is present in onion fields in Burkina Faso. High prevalence rates were noted in at least one locality per main onion growing area. However, prevalence was higher in the northern, western and central parts of the country than in the southwestern part. Almost all of the sites located in the northern zone have been heavily contaminated. This could be explained by the conditions favorable to Fusarium development prevailing in the northern zone, which are characterized by high temperatures $\left(20^{\circ} \mathrm{C}-38^{\circ} \mathrm{C}\right)$ and low relative humidity of the air. Since Fusarium is seedtransmissible, preventive measures should be taken to avoid uncontrolled transfers of seed lots from highly contaminated areas (North, West, Central) to the low-contaminated area (Southwest).

Molecular analysis of the Fusarium isolates collected in the study area has allowed to identify five Fusarium species and to note a strong distribution of two of them: F. oxysporum (44.4\% of the isolates) encountered in 10 of the 17 sites, 
and $F$. proliferatum (41.66\% of the isolates) found in eight production sites. The species $F$. solani and F. fujikuroi were each presented at two sites while $F$. thapsinum was only observed at the the single site of Ouahigouya. Several authors have previously isolated F. oxysporum from onion plants and have also highlighted the responsibility of this species in basal onion rot [8] [9] [10] [19]. $F$. oxysporum, F. solani and F. proliferatum have also been isolated from onion and garlic (Allium sativum L.) and identified as pathogenic fungi associated with seedling damping-off of young plants and/or post-harvest deterioration of bulbs [10] [11] [19] [20] [21]. Dabiré's work in 2017 [11] on the diagnosis of fungal pathogens of onion in Burkina Faso, previously revealing the presence of $F$. oxysporum in Korsimoro and Moctédo and F. solani in Sourou, are in agreement with the results obtained in this study. In the first two sites, in addition to $F$. oxysporum, the present study identified $F$. proliferatum in Korsimoro, $F$. proliferatum and F. fujukuroï in Mogtédo.

In terms of biometric characterization, the assessment of the mycelial growth speed have allowed to distinguish F. oxysporum, F. proliferatum, F. solani and $F$. fujikuroï, whose colonies grew rapidly $(7.72-8.27 \mathrm{~mm} / \mathrm{d})$ on the PDA medium, from $F$. thapsinum, which, on the other hand, experienced slow growth (6.52 $\mathrm{mm} / \mathrm{d}$ ). However, this character did not allow to distinguish the first four species from each other. The length and width of the conidia, number of cells per conidia were also not discriminating enough to clearly differentiate the five species. Thus, as some authors like O'Donnell et al. believe, [12] visual analysis alone is not enough to identify Fusarium species. Within F. oxysporum, two isolates, F.o-8-Lm and F.o-60-Kd, showed long and broad conidia (12.28 - 17.24 $\mu \mathrm{m} \times$ $1.92-3.96 \mu \mathrm{m}$ ), each with three to six cells. The conidia of these two isolates appear to be predominantly macro conidia unlike the other isolates of the species whose conidia are small in size, therefore micro conidia. Similarly, for the isolates F.pro-4-Sm; F.pro-15-R; F.pro-3-Sm of the species F. proliferatum which produced long conidia $(9.44-11.24 \mu \mathrm{m})$ having 2 to 3 cells each, their conidia appear to consist of macro conidia. For the other isolates, the majority of the conidia produced which are small in size $(<10 \mu \mathrm{m}$ long $)$ should be mainly formed by micro conidia. These results suggest the existence of different strains within the species $F$. oxysporum and $F$. proliferatium. The present study confirms that of Sumana et al. [22] who detected a strong genetic diversity in F. oxysporum $\mathrm{f}$. sp. nicotianae (from tobacco), in Karnataka, India.

\section{Conclusion}

Fungi from the genus Fusarium have been detected on onion plants in Burkina Faso at rates ranging from $10 \%$ to $90 \%$. Molecular analysis of 36 Fusarium isolates collected from different onion production sites identified five Fusarium species including F. oxysporum, F. proliferatum, F. solani, F. fujikuroi and $F$. thapsinum. Fusarium oxysporum and $F$. proliferatum, which accounted for $44.44 \%$ and $41.46 \%$ of isolates, respectively, were the most representative species 
in all the production areas. The bio-morphological study showed that $F$. oxysporum, $F$. proliferatum, F. solani, $F$. fujikuroi had faster mycelial growth on PDA medium than $F$. thapsinum. The identified Fusarium species, in particular, $F$. oxysporum and $F$. proliferatum, regrouped within them, isolates whose conidia were predominantly composed of macro conidia and other isolates whose conidia were mainly composed of micro conidia. These results suggest the existence of different strains within each of the Fusarium species. A pathogenic characterization of the different isolates would allow, on the one hand, to identify the Fusarium species involved in seedling damping-off and basal bulb rot, two major pathologies of onion in Burkina Faso, and on the other hand, to determine the most pathogenic Fusarium strains. Precise knowledge of these pathogens is essential for the development of adequate and sustainable management methods for these diseases.

\section{Acknowledgements}

The authors would like to thank the Congregation of the Sisters of the Immaculate Conception of Ouagadougou (S.I.C.O.) and the Institute of Environment and Agricultural Research (INERA) for their financial support for this work. They also thank the staff of the CREAF Phytopathology Laboratory for their efforts in collecting and processing samples and LMI Patho-Bios for their technical assistance in molecular biology analysis.

\section{Conflicts of Interest}

The authors declare no conflicts of interest regarding the publication of this paper.

\section{References}

[1] Tarpaga, W.V. (2012) Contribution à l'étude de la montaison prématurée des variétés tropicales d'oignon (Allium cepa L.): Cas du Violet de Galmi, cultivé au Nord du Burkina Faso. Thèse de Doctorat, Université de Ouagadougou, Burkina Faso, 120.

[2] DPSAA (2011) Analysis Report of the Market Gardening Module. Central General Census Office of Agriculture, Ministry of Agriculture, Hydraulics and Fisheries Resources, Burkina Faso, 237 p.

[3] Ministère de l'Agriculture et de l'Hydraulique (MAH)/DGPER/DPSAA, Bureau central du recensement général de l'agriculture (2011) Phase 2 RGA 2006-2010. Rapport du module maraîchage. Ouagadougou, Burkina Faso.

[4] White, K. and Zellner, J. (2008) Onion. The Science, Culture and Politics of Food. 29.

[5] Oudet, M. (2011) La filière oignons: Une filière peu organisée mais pleine d'avenir. In: ABC Burkina, Vu au Sud-Vu du Sud, Numéro 421.

[6] Schwartz, H.F. and Mohan, K.S. (2008) Basal Rot of Onion. In: Compendium of Onion and Garlic Diseases, 2è Edition, APS Press, American Phytopathological Society, Saint Paul, MN.

[7] Nelson, P.E., Horst, R.K. and Woltz, S.S. (1981) Fusarium Diseases of Ornamental 
Plants. In: Nelson, P.E., Toussoun, T.A. and Cook, R.J., Eds., Fusarium: Diseases, Biology and Taxonomy, The Pennsylvania State University Press, University Park, PA, and London, 121-128.

[8] Conn, E.K., Lutton, J.S. and Rosenberger, S.A. (2012) Onion Disease Guide. A Practical Guide for Seedmen, Growers and Agricultural Advisors. Seminis Grow Forward, $69 \mathrm{p}$.

[9] Zlata, D., Jelena, T., Stevan, N., Jelica, M., Mijana, A. and Svjetlana, R. (2008) Fusarium Rot of Onion and Possible Use of Bioproduct. Matica Srpska Journal of Natural Sciences Archives, No. 114, 135-148. https://doi.org/10.2298/ZMSPN0814135K

[10] Ghanbarzadeh, B., Goltapeh, E.M. and Safaie, N. (2014) Identification of Fusarium Species Causing Basal Rot of Onion in East Azarbaijan Province, Iran and Evaluation of Their Virulence on Onion Bulbs and Seedlings. Archives of Phyto-Pathology and Plant Protection, 47, 1050-1062.

https://doi.org/10.1080/03235408.2013.829628

[11] Dabiré, T.G. (2017) Diagnosis, Characterization of Fungal Diseases of Onion (Allium Cepa L.) in Market Gardening Agrosystems in Burkina Faso. PhD Thesis in Agronomic Sciences and Biological Engineering, University Catholique de Louvain, Belgium, $256 \mathrm{p}$.

[12] O’Donnell, K. and Cigelnik, E. (1997) Two Divergent Intragenomic rADN ITS2 Types within a Monophyletic Lineage of the Fungus Fusarium Are Nonorthologous. Molecular Phylogenetics and Evolution, 7, 103-116. https://doi.org/10.1006/mpev.1996.0376

[13] Mathur, S.B. and Kongsdal, O. (2003) Common Laboratory Seed Health Testing Methods for Detecting Fungi. Kandrups Bogtrkkeri Publication, Denmark.

[14] Sadfi, Z., Hannachi, I. and Andurand, D. (2008) Springer Infection of Tomato Stem Wounds by Botrytis Cinerea Is an Important Problem Which Can Cause Severe Economic Losses in Greenhouse Tomato Crops. Three Moderately Halophilic Bacteria Were Tested for Their Ability to Protect Pruning Wounds from Attacks by B. Cinerea. World Journal of Microbiology and Biotechnology, 24, 2871-2877. https://doi.org/10.1007/s11274-008-9825-0

[15] White, T.J., Bruns, T., Lee, S. and Taylor, J. (1990) PCR Protocols. Academic Press, San Diego, CA, 315-322. https://doi.org/10.1016/B978-0-12-372180-8.50042-1

[16] O’Donnell, K., Cigelnik, E. and Nirenberg, H.I. (1998) Molecular Systematics and Phylogeography of the Gibberella Fujikuroi Species Complex. Mycologia, 90, 465-493. https://doi.org/10.1080/00275514.1998.12026933

[17] Genewiz http://www.beckmangenomics.com/

[18] http://blast.ncbi.nlm.nih.gov/Blast.cgi

[19] Sasaki, K., Nakahara, K., Tanaka, S., Shigyo, M. and Ito, S.I. (2015) Genetic and Pathogenic Variability of Fusarium Oxysporum f. sp. Cepae Isolated from Onion and Welsh Onion in Japan. Phytopathology, 105, 525-532. https://doi.org/10.1094/PHYTO-06-14-0164-R

[20] Sankar, N.R. and Babu, G.P. (2012) First Report of Fusarium Proliferatum Causing Rot of Garlic Bulbs (Allium sativum) in India. Plant Disease, 96, 290. https://doi.org/10.1094/PDIS-08-11-0649

[21] Shehu, K. and Muhammad, S. (2011) Fungi Associated with Storage Rots of Onion Bulbs in Sokoto. Nigeria. International Journal of Modern Botany, 1, 1-3. https://doi.org/10.5923/j.ijmb.20110101.01 
[22] Sumana, K., Punith, B.D. and Devaki, N.S. (2014) First Report on Molecular and Biochemical Variations among the Populations of Fusarium Oxysporum Infecting Tobacco in Karnataka, India. International Journal of Agricultural Technology, 10, 931-950. 